\title{
Oral textual patterns in modern advertising
}

\author{
Marta Wójcicka
}

\begin{abstract}
The aim of this article is to describe structural patterns used in modern advertising, both on the level of single ads (opposition, collections) as well as in advertising campaigns (equivalence-based patterns, implicit numerical patterns). These patterns, described originally by the Ethnolinguistic School of Lublin (see e.g. Bartmiński 1998; for an overview, see Zinken 2004) are typical also of oral texts. The constructional patterns shared by both oral texts and advertisements will be exemplified by ads of one brand of Lublin beer, Perta ('Pearl').
\end{abstract}

Keywords: oral text, structural patterns, opposition, advertising

The advertisement is a genre characterised by semiotic heterogeneity (Lewiński 1999: 41), and is a culture-specific message incorporating various codes. ${ }^{1}$

The aim of this article is to describe the structural patterns (e.g. proverbs, sayings) used in modern advertising, which are typical examples of traditional, formulaic, oral texts. The constructional patterns shared by both oral texts and advertisements will be exemplified by ads of one brand of Lublin beer, Perta ('Pearl'). The data used for this study consists of billboards from the years 1999-2011.

Both individual billboards as well as advertising campaigns of the brand as a whole will be treated as texts, i.e. complex macrosigns, characterised by specific stylistic and genological attributes, but also by structural and semantic coherence. They lend themselves well to holistic semantic interpretation, internal semantic division, and (in the case of longer texts) logical and compositional analysis (Bartmiński 1998).

${ }^{1}$ Rafał Zimny's book (Zimny 2008) is a good overview of studies in advertising. 


\section{Advertisement as a text}

Textual aspects of advertisement are highlighted by the term "advertisement text", which is commonly used by scholars and defined by Rafał Zimny as "a polysemiotic creation, whose content results from the interaction of semiotic domains, which form a complete image" (Zimny 2008: 117). An advertisement text is therefore

a specific unit (constituting a part of a bigger advertisement discourse) built from a combination of signs belonging to various codes, determined situationally, contextually and culturally. An advertisement is clearly distinguished from other messages performing the same function and other textual messages of all kinds. It is also interpretable as a macrosign with a coherent structure. An advertisement is a distinctive genre of speech or assumes a distinctive genre of speech in the form of a monolog, dialog, or polylog, whose main functions are encouraging the addressee to purchase a particular product, making use of a particular paid service (the obligative function), or informing about them (the non-obligative function) (Zimny 2008: 117).

In the first part of the article, separate advertisement texts will be analysed, without taking into consideration the links and interrelationships between various texts in a single campaign.

The dominant organisational patterns of Perta advertisement texts are opposition and collection, and in the following sections we will discuss them in more detail.

\section{Opposition in Perta advertisements}

Opposition is one of the basic mechanisms of structuring the worldview. At the same time, it is one of the main patterns for organising oral texts, often to be found in love songs, orphan songs and magical fables (cf. NiebrzegowskaBartmińska 2007: 308-323).

In advertisements, three types of opposition are used:

1) oppositions of spatial relations (e.g. left-right - on the level of the iconic code),

2) semantic oppositions on the level of both iconic and verbal codes,

3) oppositions between verbal and visual aspects of the advertisement.

The first type of opposition appeared, among others, in advertisements of the 2009 campaign titled "Doskonałość" ("Perfection”). Here, the opposition operates 
solely on the iconic level. Every text of this campaign is built according to the same constructional principle: on the right, there is a photograph of a slightly tilted bottle of Perta, on the left there is a photograph of a woman. The slogan does not illustrate or comment on the iconic code. This structuring of the text on the level of the iconic code points to a clear axiological orientation, entrenched in both culture and language. In Polish one of the meanings of the word lewy ('left') is 'illegal, false, fake' and 'suspicious'; also: 'inadequate due to lack of certain skills', and pójść na lewo ('go to the left') has the colloquial meaning of 'acting illegally' (cf. Szymczak 1995: 28). On the other hand, prawy ('right') connotes positive values and denotes, among other things, 'noble, honest' as well as 'legal, legitimate, rightful'. Thus, the beer which is presented on the right side of the billboard is attributed positive values, whilst the object on the left is valued negatively (probably in a jocular manner) and in opposition to the beer. The object placed in the opposition is a woman. A man, who is an intended addressee of this advertisement, is to make a choice between the woman and the beer.

The axiologically charged spatial orientation, which can be found in many folk texts, where the right side is valuated positively and the left side negatively, is used in several advertisements of Perta. This layout can be explained in terms of psychology, influencing the consumers' decisions. One of such ploys is defined by Dariusz Doliński as "the rule of the right hand stating that a product should be placed to the right of the best known product of a particular line of business" (Doliński 2001: 44-46).

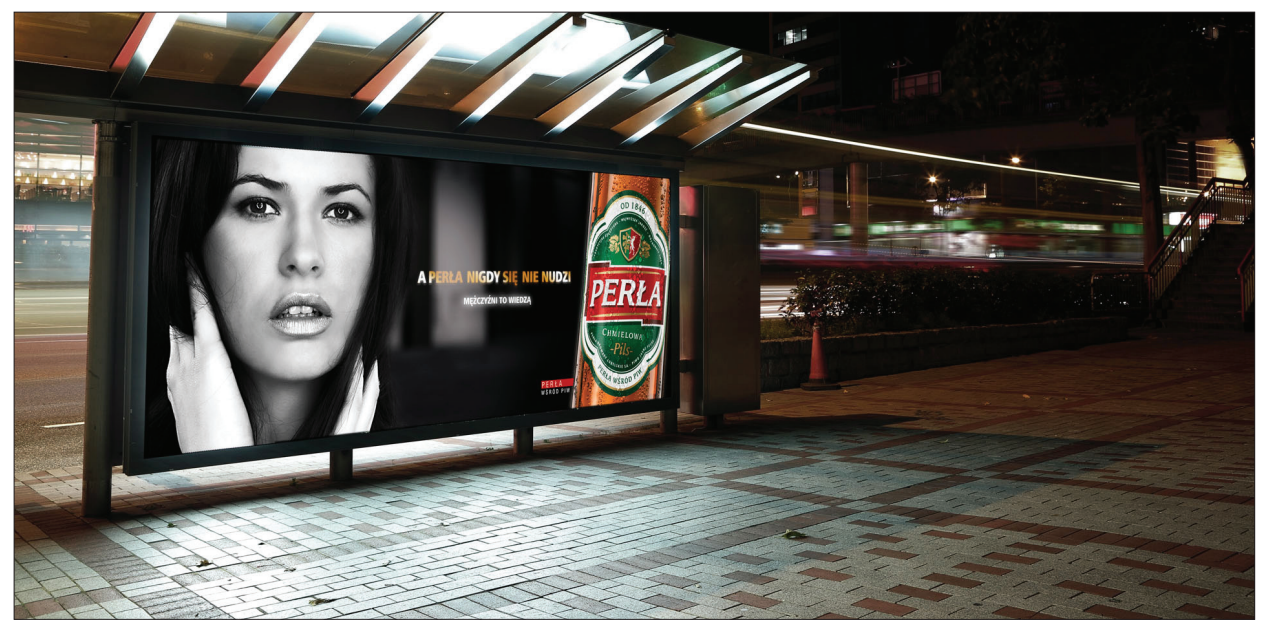

Figure 1. Opposition functions on the level of the iconic and the verbal codes ("And you'll never be bored with Perta”). Perta advertisement, 2010. 
The second type of opposition functions on the level of the iconic and the verbal codes, and can be found in the text of the advertisement from 2010. Once again there is a clear axiological organisation of the billboard space: similarly to the texts from 2009, there is an image of Perta on the right, while on the left, several images of women are placed. This layout is accompanied by bipartite slogans: one part starts with the conjunction a ('and'): A Perta nigdy się nie nudzi ('And you'll never be bored by Perta'; see Figure 1), A Perta dobra, kiedy zimna ('And Perta is good when it's cold'), A Perta chętnie się dzielisz ('And you willingly share Perta with others'), A Perta jest piękna, gdy się pieni ('And Perta is beautiful when it's foaming'), while the other part summarises the conclusions from the two codes: Mężczyźni to wiedza ('Men know this').

This structuring of the slogan reflects the meaning of the billboard's spatial organisation. The verbal code and the iconic code convey the same information, both have the same valuation. Women and beer are juxtaposed, but even though they may share certain characteristics (they can be cold, they can be shared, they "foam"), these characteristics are advantages for Perta, and disadvantages for women. The result of this comparison and juxtaposition of Perta and women is positive for Perta, which is emphasised both iconically and verbally.

The third type of opposition, the opposition between codes, can be found in the campaign from 2003. The first opposition appears on the level of the iconic code, as the billboard resembles a torn holiday photograph. It features two objects: a woman (in sunglasses, on a lounger, or standing in water) and Perta. The tear between the two halves of the photograph puts these objects in op-

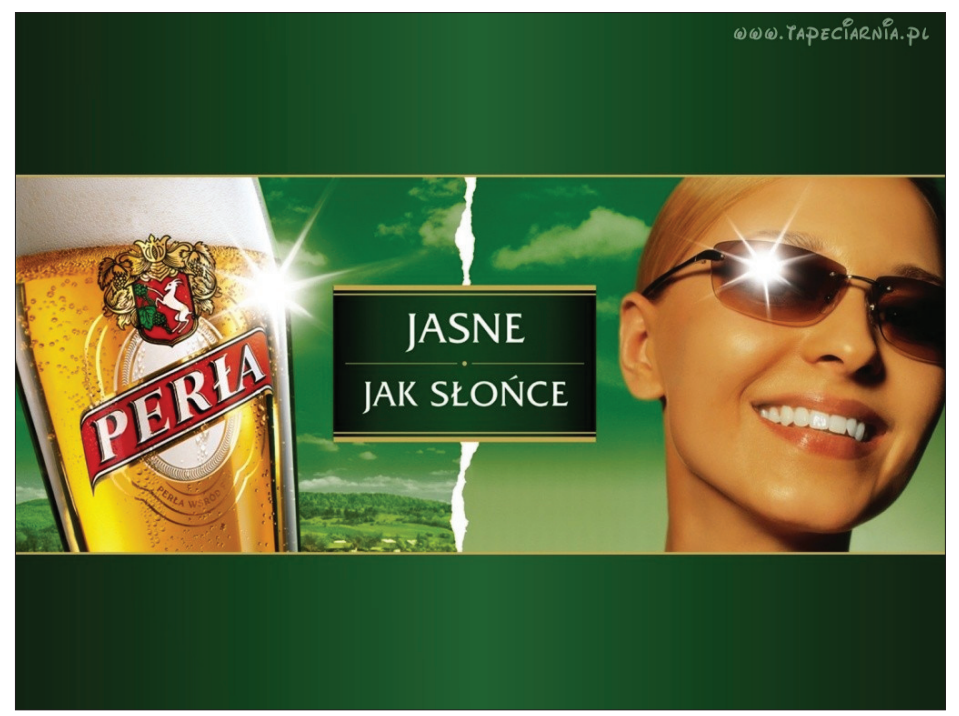

Figure 2. Opposition between two codes ("As bright as the sun”). Perta advertisement, 2003. 
position. On the level of the verbal code, the message opposes the one conveyed by the iconic code: the two halves are "linked" by slogans placed in the center Jasne jak stońce, Lodowata pożądana, Zimna na goraco, Perliście chtodna ('As clear/bright as the sun', 'Ice-cold and desired', 'Cold against the heat', 'Pearly cool'). Even though the first information, i.e. Jasne jak stonce ('As clear/bright as the sun', see Figure 2), could reinforce the meaning from the iconic code, presupposing that the slogan concerns the choice made by someone who tore the photograph, the other slogans of this campaign (given that the campaign is structured logically and coherently) point to an opposition between the messages communicated by the two codes; the opposition seems to be a kind of play on signs directed at the addressee.

On the level of the iconic code, the authors of the billboard have made use of opposition, on the level of the verbal code, of collection (see below for discussion): the two objects are 'as clear/bright as the sun', 'ice-cold and desired', 'cold against the heat', 'pearly cool'. These slogans include the keywords "clear" and "full" used in other campaigns of Perta: W petni jasnych świąt ("[We wish you] a fully clear/bright Christmas') from 2004, Petna temperamentu ('Full of character') in 2004, Petna naszej historii ('Full of our history'), Petna naszej tradycji ('Full of our tradition'), Petna chmielu ('Full of hops'), Petna radości ('Full of joy') from 2006, Petna lekkości ('Full of lightness'), Petna charakteru ('Full of character') from 2007.

\section{Collection in Perta advertisements}

According to Jerzy Bartmiński, a collection is "a set of objects belonging together in a naïve, rather than scientific, understanding" (Bartmiński 1990: 18). It signifies an array of coexisting objects (events, features, etc.) related to each other on the grounds of tradition or a point of view. For example, a collection may be formed on the grounds of experiencing things as belonging together from a subject's point of view, e.g. a saw, an axe, and a log belong together functionally, because the saw and the axe would be useless without the log. Reasoning on the basis of collections seems to be more characteristic of people living in traditional communities (see also Zinken 2004: 119).

Advertisements employ the pattern (used in folk texts as well) based on a collection of objects whose elements meet three requirements: 1) they coexist in the same place in space, 2) they coexist in the same moment in time, 3) they have the same role in an event, they are "isofunctional" (Bartmiński 1990: 161). For example, in the case of the analysed examples, both beer and women are:

- objects of desire. In the case of women, it is illustrated by the proverb Gdzie jest miód, tam będa i pszczoty, gdzie piękna dziewczyna, tam będa 


\section{Marta Wójcicka}

$i$ chtopcy ('Where honey is, bees will come, where a beautiful girl is, boys will come');

- generously endowed by nature;

- excessively talkative. In the case of women, it can be interpreted as a tendency to express their emotions, especially verbally, as illustrated by the proverbs Dwie gęsi, trzy niewieście uczynity jarmark w mieście ('Two geese and three women made a bazaar in the town'), Chtop robotny, zona pyskata - zdobęda pót świata ('A hard working man, a brazenly talking wife - they'll conquer half the world');

- $\quad \operatorname{cold} /$ calculating. This attribute is emphasised by the following proverbs concerning women: Kiedy pies śpi, Żyd przysięga, pijany się modli, a białogłowa płacze, rzadko wierzyć trzeba ('Seldom should one believe when a dog sleeps, a Jew promises, a drunk prays, and a woman cries'); Gdzie diabet nie może tam babe pośle ('Where the devil cannot go, he'll send a woman'); Trzeba rano wstać, żeby babę oszukać ('One must wake up early in the morning to deceive a woman').

These attributes evoke a stereotypical image of a woman. This image is present also, as we saw in the examples above, in proverbs, which quote the respective attributes (cf. Jędrzejko 1994).

Collection appears in the advertisements of Perta from 2011. Even a cursory comparison of the product's campaigns shows important changes in the use of colour: the traditional green has now been replaced with red, but the distinctive and recognisable bipartite division of the billboard is retained, as the photographs depict Perta beer and a woman. A new feature is the alternating spatial organisation in consecutive advertisements: in one text the beer is placed on the right, while in the following text the beer appears on the left. Nonetheless, here the space of the billboard is not formally divided ("torn" as in the previous examples). Between the objects, the authors of the billboard have placed the slogans: Zimna, a wspomnienia ciepte ('Cold, but the memories are warm'); Zachowała czystość ('It has kept its purity'); Wylewna w dobrym towarzystwie ('Effusive in good company');' Natura byta szczodra ('Nature was generous'); Gasi pragnienie, budzi pożadanie ('Quenches thirst, wakes desire'). The other part of the slogan is always the same: dlatego jest niezwykta ('therefore it's exceptional').

From the point of view of the advertisement's male addressee, a woman and Perta are a collection of objects that share the attributes highlighted by the slogans; they perform the function of objects which are collected and compared by the "real man". At the same time, the texts of these advertisements trigger

${ }^{2}$ In Polish the word wylewna is typically used metaphorically to denote 'talkative', but in a more "literal" reading it can be interpreted as 'easy to spill' (from wylewać, 'to spill'). 
a conceptual metaphor BEER IS A WOMAN, as both Perta and a woman are characterised by similar stereotypes in a naïve understanding.

\section{Advertising campaign as a text}

An advertising campaign, embracing several advertisements that develop one main topic, can be treated as a text. Such a text consists of several thematically (and often also structurally) related segments, forming one single advertisement. A campaign conveys a holistic message, hinging upon a single main idea, developed in particular advertisements.

In the campaigns of Perta beer analysed in this article, the following patterns can be found:

- equivalence-based patterns;

- general textual patterns;

- implicit numerical patterns linked to a sequence of events, surrendering to, for example, the rule of three.

\section{Patterns based on equivalence}

Equivalence in linguistics can be viewed as "a relation of balance between various elements of the text, as far as content and style are concerned" (NiebrzegowskaBartmińska 2007: 362). The term groups objects that function in a similar way; e.g. the sun is like gold, because it makes the earth golden, and like fire, because it burns and warms (Zinken 2004: 120). According to Stanisława Niebrzegowska-Bartmińska, equivalence is formed by repetition which appears across different variants of the text (e.g. different billboards) or within the text itself (on a single billboard; Niebrzegowska-Bartmińska 2007: 362). Intratextual equivalence, observable in many campaigns of Perta, is "an example of balance between elements appearing in all or several parts or segments of one text" (Niebrzegowska-Bartmińska 2007: 365).

Intratextual equivalence is the basis for most of Perta's campaigns. Two examples have been chosen for a more detailed analysis, i.e. the campaigns from 2000 and 2001/2004. The former is based on the slogan Perta wśród piw ('The pearl among beers', see Figure 3). The text of the campaign consists of five segments, i.e. five advertisements sharing the same slogan, but with different pictorial elements. The construction of every segment is guided by the same principle. The elements appearing in all advertisements are:

- $\quad$ vertical bipartite division of the billboard; 


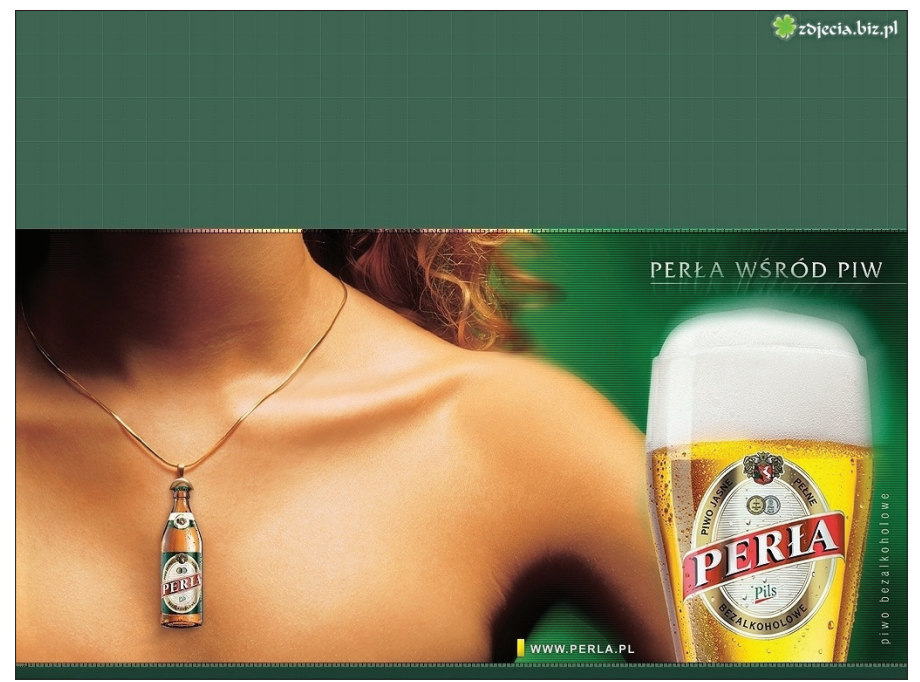

Figure 3. Example of equivalence in advertisements (The pearl among beers). Perta advertising campaign 2000.

- a photographic image of a part of a female or male body on the left side of the billboard;

- a photographic image of a part or the entire bottle of Perta beer on the right of the billboard;

- green background;

- a miniature bottle of Perta beer presented as a part of female or male jewellery;

- the slogan Perta wśród piw ('The pearl among beers'), which is a play on words hinging on homonymy: Perta is a proper name of the beer brand and at the same time a precious stone, with the transition of meaning from the latter to the former.

The changing elements, the equivalents in the intratextual space in discussion, are parts of female or male body and the function of the miniature beer bottle. The bottle is shown as a neck pendant, an earring, a waist pendant, a bracelet or, in one advertisement, as a cuff-link of a men's shirt.

Equivalence has also been used in the text of the advertising campaign from 2001 and 2004. The fixed elements in the 2001 campaign are (for example, see Figure 4):

- the slogan Perta wśród piw;

- background colour (bottle green); 


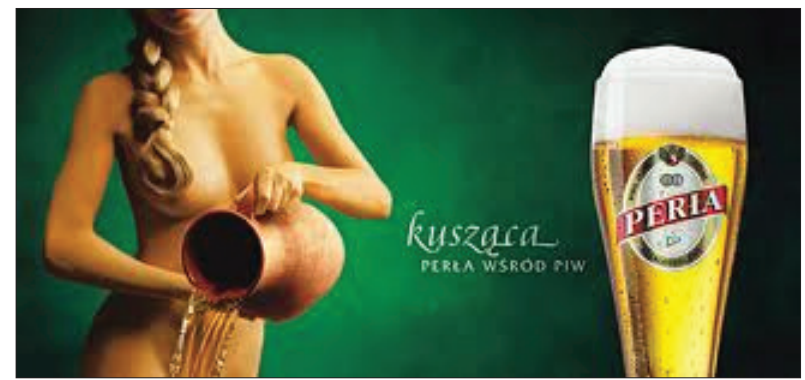

Figure 4. Example of equivalence in advertisements (Tempting). Perta advertising campaign 2001/2004.

- spatial organisation of the billboard: on the right, a bottle of beer; on the left, a part of female body (always the same, spanning from the neck to the thighs);

- the slogan situated between the two images.

The equivalents are:

- colour of the female body: golden or various shades of green;

- the slogans: Złocista ('Golden'), Chmielowa ('Made from hops'), Orzeźwiająca ('Refreshing'), Kusząca ('Tempting'), Naturalna ('Natural') presenting attributes of the beer. The slogans reveal positive qualities of the beer and point to the fact that the entire campaign should be treated as a holistic message built from complementing segments, i.e. the advertisements. The number of the segments seems to be meaningful as well: the symbolism of the number five, which is the combination of two and three, stands for an exceptionally good fortune in Polish culture;

- attributes accompanying women: gold, hops, water, a jar of water, a wreath. All these attributes carry a significant meaning. Also, gold symbolises perfection: "Gold is a symbol of divinity due to the fact that in the ancient world the metal was commonly associated with the sun, and because of its extraordinary shine, resistance to rust, durability, and ductility. Its emblematic properties involve stainlessness, refinement, spiritual enlightenment, truth, harmony, and wisdom, as well as earthly rule, glory, majesty, nobility of attitude, and riches" (Tresidder 2005: 255; see also Iżykowska 2013, this volume).

Hops is on the one hand the main ingredient of the advertised beer, and on the other, it evokes numerous symbolic senses, for example, it is mentioned in one of the oldest Polish wedding songs performed during the ritual of oczepiny (the unveiling and capping ceremony): 
Żebyś ty chmielu po tyczkach nie laz, Nie robit ty byś $z$ panienek niewiast.

Oj, chmielu, oj, nieboże,

Niech ci Pan Bóg dopomoże, Chmielu nieboże.

Ale ty chmielu po tyczkach tazisz, Niejedno panne $z$ wianka pozbawisz.

Oj, chmielu, oj, nieboże, Niech ci Pan Bóg dopomoże, Chmielu nieboże. ${ }^{3}$
If you, hops, didn't crawl the pole, You wouldn't turn maidens into women. Oh, hops, you poor thing, May God help you, Hops, you poor thing. But you, hops, crawl the poles, More than one maid you deprive of her wreath.

Oh, hops, you poor thing, May God help you, Hops, you poor thing.

In the Polish folk culture, the wreath mentioned in the song and shown on the Perta billboard is an attribute of an unmarried woman and symbolises chastity. In the advertisement, the beer and an unmarried woman seem to share many qualities, mainly purity, and for this reason the campaign compares Perta to a maid (unmarried woman).

Water is yet another symbol used in this campaign. Water is "an ancient universal symbol of purity, fertility, good harvest, the source of life itself" (Tresidder 2005: 244).

The symbols used in this campaign evoke the keywords shared by all campaigns of Perta: perfection (gold), chastity (wreath), purity (water). All of them are related to women, whose image can be found on almost every billboard of this brand. At the same time, on the level of the iconic code, presenting a part of a woman's body is a metonymy.

Equivalence in the intertextual space, i.e. the balance between several variants of a text, can be found in the campaign from 2002. This campaign's key slogan is Od dawna znamy ksztatt Twoich pragnien' ('We have known the shape of your desires for a long time'); it advertises and presents Perta as the main sponsor of Prowokacje 2002, and makes use of many variants typical of oral texts. In this case, there are three advertisements rendered in two variants. The changing details are a part of woman's body wrapped in a piece of white cloth and a mug of beer with white foam. The white cloth resembles white foam; the woman's body corresponds to the mug of beer. The advertisement features the back, backsides, part of legs or whole legs on one side and a mug of beer on the other, which are photographed in such a way that they are silmilar in the advertisement. In this campaign, the described equivalence is linked with an implicit numerical pattern: there are three texts altogether and the number

${ }^{3}$ Cf. Adamowski 1994: 57. 
three denotes completeness, wholeness and finiteness, which, associated with the slogan of the campaign, suggests that the brand knows the shape of all men's desires.

The same principle (equivalence in the intertextual space linked with an implicit numerical pattern) was used in another campaign from the same year, 2002, with the slogan of Idealny ksztatt ('The ideal shape'). The consecutive billboards of this campaign can be treated as textual variants of one message. The changing elements are:

- the second part of the slogan, which appears in the following variants: Idealny ksztatt, doskonaty pretekst ('Ideal shape, perfect pretext'); Idealny ksztatt, doskonaty smak ('Ideal shape, perfect taste') and Idealny ksztatt nie przemija ('Ideal shape doesn't wane');

- a technical drawing of a bottle used as the background of the billboard.

\section{General textual patterns in the campaigns}

On the basis of the above analysis, each campaign can be described as having the following aspects:

- it has an originator: Perta's producer and the campaign's designer;

- it has a recognisable intention, enabling interpretation on the part of the addressee (promoting the brand);

- it has stylistic (and genre) attributes which distinguish the campaign from other campaigns of this brand through, for example, its slogan and graphic conventions;

- it can be interpreted holistically (e.g. as a macrostructure consisting of three chronologically ordered sequences);

- it is characterised by structural integrity and semantic coherence (e.g. achieved through developing the subject matter of the campaign's slogan, 'The pearl among beers', with slight variations within different billboards);

- it is liable to internal semantic division, and (in the case of longer texts) logical and compositional analysis (cf. Bartmiński \& NiebrzegowskaBartmińska 2009: 36).

At the same time, each advertisement of any campaign can be viewed as a separate, integral, communicationally independent text. 


\section{Significance of numerical patterns in Perta advertisements}

Implicit numerical patterns organise the structure of a text, and can be found in folk riddles, convivial, but also funeral songs, love songs, prayers and Christmas carols.

The rule of three mentioned above was used in Perta's advertising campaign in 1999 (see also Järv 2013, this volume). The campaign involved three similarly structured billboards, consisting of the following elements:

- the slogan: Moje piwo, moja perta ('My beer, my pearl');

- phrases based on the same verb;

- explicit bipartite division of the billboard, exemplifying the principle of opposition;

- constant, axiologically charged, spatial organisation of the billboard (a bottle of beer on the left, slogans at the top of every advertisement, and at the bottom on the left an additional image complementing or illustrating the slogan).

Thus, the 1999 campaign as a whole can be treated as a macrotext, embracing chronologically organised texts which belong to particular advertisements. The symbolic significance of the number three is rich and complex: it may stand for completeness or closure (Tresidder 2005: 226), but can be referred to also as having "become the basic scheme for understanding the world" (Chanel \& Simarro 2008: 267), referring to the "solution of the conflict created by dualism" (Cirlot 2007: 225). In the text of the campaign analysed here, the number three seems to denote completeness and finiteness. The numerical pattern introduced in the campaign enables gradation of particular components up to the point where a perfect state is reached, which in this campaign can be seen as becoming acquainted with the beer and feeling the sense of solidarity with other people acquainted with the beer.

On the level of the linguistic code, the chief motif in all three billboards is the verb znać ('to know') appearing in all slogans. The three advertisements form a sequence of events, starting from not knowing the beer (similarly to the functions of the protagonist in the realm of magical fables as described by Propp (1968), ending with acquiring the object that was originally missing. Thus, the campaign is built upon the pattern of a sequence, that is, it features various combinations of closely related activities, organised chronologically or causally.

The advertisement Cudze chwalicie ... ('You praise what is somebody else's ...') is chronologically the first advertisement of this campaign, followed by Znam się na rzeczy ('I know my stuff') and Poznajmy się bliżej ('Let's get to know each other better'). The first of these examples contains an intertextual reference to a 
Polish proverb: Cudze chwalicie, swego nie znacie ('You praise what is somebody else's, you don't know what is yours', often also translated as 'Grass is always greener on the other side'). The predominant element is the second person plural pronoun $w y$ ('you'). The pronoun $w y$, just like the second person singular pronoun $t y$ (frequently used in advertisements), performs various functions: it endows the message with a gnomic sense and it also approaches directly a certain group of addressees and attracts attention (cf. Zimny 2008: 283). At the same time, the pronoun $w y$ renders the addressee as a part of a group of people unacquainted with the advertised product. This suggests that a person unfamiliar with the beer does not deserve to be treated as an individual, belongs to a homogeneous crowd, and is completely submerged in this crowd. As Zimny notes, following the work of Sulima (2000: 54), the plural pronoun wy is a marker of social interrelations, it "unites all members of the created community" (Zimny 2008: 284) unacquainted with the advertised product. The advertisement addresses an unspecified person unfamiliar with Perta. The slogan is illustrated with the image of two mugs of beer knocking against each other.

The second advertisement uses the first person singular pronoun ja ('I'). In the phrase "I know my stuff" the personal pronoun "I" is ambiguous: it can both refer to the brand of the beer advertised (the slogan involves a presupposition that Perta brewery has the expertise required for producing beer) or an unspecified voice, a "real man" who "knows his stuff" and can add Perta to his collection. The latter possibility is supported by the fact that the beer is presented next to an outline of the female body, and such a layout can be considered to be a collection, which was discussed in the first part of the present article.

The third advertisement is based on the first person plural personal pronoun $m y$ ('we'), which serves the aim of creating a sense of community and relationship. Therefore, this advertisement complements and concludes the previous ones.

These chronologically ordered billboards reflect three stages of interpersonal relationships highlighted by the personal pronouns: $w y$ ('you') $+j a$ ('I') = $m y$ ('we'). Each of them constitutes chronologically ordered patterns of three. Thus, just like in the case of traditional oral texts, the number of sequences is motivated here by the number of the main participants. In the advertisements of Perta in 1999, three main participants indicated by the personal pronouns appear ("you praise what is somebody else's" -> "you don't know", "I know" -> "let's get to know each other"), which is why the campaign comprises three sets of advertisements. 
Each of these billboards has a different purpose. The first one evokes a proverb which admonishes the addressee for not knowing the brand. The second one is to encourage the addressee to add Perta to those items that he knows are good and which would confirm the addressee's masculinity (a woman and beer). The third one uses the plural verb form and the syntactic pattern of a request to encourage a closer relationship between the addressee and the brand, presented as partners in the discourse.

\section{Conclusion}

To sum up, advertisements are often considered to be “'a parasitic phenomenon' making use of what is already known to addressees. In order to encourage the consumer to purchase a product, advertisements may evoke all available meanings, myths, traditions, and rituals pertaining to both high and low culture" (Zimny 2008: 43). I believe that as far as meanings and linguistic tools are concerned, advertisements evoke texts that are known to addressees and engage them in a kind of linguistic and intertextual game, and with regard to the structure of the text, they conjure the most prototypical patterns of communication, i.e. the oral patterns. They comply with one out of four criteria of typical advertisement texts as formulated by Geoffrey Leech (1966), who claims that an advertisement text should be remembered or at least recognised as familiar and in order to achieve this, it uses the oldest and the most commonly used structural patterns of communication: opposition, collections, equivalencebased patterns, and implicit numerical patterns.

As the presented analysis has shown, both the single advertisements and the whole advertising campaigns of a given brand can be seen as a text. The latter is a complex text, with the core message manifested by the slogan of the campaign. It shows a chronologically ordered, complex structure, which consists of simple texts, i.e. particular advertisements. The sequence of the advertisements that make up the advertisement campaign is not accidental. They constitute a macro-sign (campaign), which is logically and semantically ordered. 


\section{References}

Adamowski, Jan 1994. Tam na Podlasiu. Pieśni ludowe z gminy Borki i ich wykonawcy. [Over there in Podlasie. Folk songs from the Borki county and their performers.] Lublin: Wyd. Hejnał.

Bartmiński, Jerzy 1990. Kolekcja w strukturze tematycznej tekstu ustnego. [Collection in the thematic structure of an oral text.] In: T. Dobrzyńska (ed.) Tekst w kontekście. Zbiór studiów. [Studies on the text in the context.] Wrocław: Zakład Narodowy im. Ossolińskich, Wyd. PAN, pp. 155-174.

Bartmiński, Jerzy 1998. Tekst jako przedmiot tekstologii lingwistycznej. [Text as an object of linquistic textology.] In: B. Boniecka \& J. Bartmiński (eds.) Tekst. Problemy teoretyczne. [Text. Theoretical issues.] Lublin: Wyd. UMCS, pp. 9-25.

Bartmiński, Jerzy \& Niebrzegowska-Bartmińska, Stanisława 2009. Tekstologia. [Textology.] Warszawa: PWN.

Cirlot, Juan Eduardo 2007. Stownik symboli. [Dictionary of symbols.] Kraków: Znak.

Chanel, Alvaro Pascual \& Simarro, Alfonso Serrano 2008. Stownik symboli. [Dictionary of symbols.] Warszawa: Świat Książki.

Doliński, Dariusz 2001. Psychologia reklamy. [Psychology of advertising.] Wrocław: Wyd Aida.

Iżykowska, Małgorzata 2013. Money as an object of desire in Silesian folklore. In: L. Laineste \& D. Brzozowska \& W. Chłopicki (eds.) Estonia and Poland: Creativity and tradition in cultural communication, Vol. 2: Perspectives on national and regional identity. Tartu: ELM Scholarly Press, pp. 231-248.

Jędrzejko, Ewa 1994. Kobieta w przysłowiach, aforyzmach i anegdotach polskich. Konotacje i stereotypy. [Woman in Polish proverbs, aphorisms, and anecdotes. Connotations and stereotypes.] In: J. Anusiewicz \& K. Handke (eds.) Płeć w języku i kulturze. [Sex in language and culture.] Vol. 9. Wrocław: Wiedza o Kulturze, pp. 159-172.

Järv, Risto 2013. A hen who doesn't lay golden eggs?! Fairy tale advertisements and their strategies. In: L. Laineste \& D. Brzozowska \& W. Chłopicki (eds.) Estonia and Poland: Creativity and tradition in cultural communication, Vol. 2: Perspectives on national and regional identity. Tartu: ELM Scholarly Press, pp. 99-120.

Leech, Geoffrey N. 1966. English in advertising: A linguistic study of advertising in Great Britain. London: Longman.

Lewiński, Piotr H. 1999. Retoryka reklamy. [The rhetoric of advertising.] Wrocław: Wyd. Uniwersytetu Wrocławskiego.

Niebrzegowska-Bartmińska, Stanisława 2007. Wzorce tekstów ustnych w perspektywie etnolingwistycznej. [Patterns of oral texts: An ethnolinguistic approach.] Lublin: Wyd. UMCS.

Propp, Vladimir 1968 [1928]. Morphology of the folk tale (transl. Laurence Scott). Austin and London: University of Texas Press. 


\section{Marta Wójcicka}

Sulima, Roch 2000. Antropologia codzienności. [Anthropology of everyday life.] Kraków: Wyd. UJ.

Szymczak, Mieczyslaw 1995. Stownik języka Polskiego. [Dictionary of the Polish language.] Warszawa: Wydawnictwo Naukowe PWN.

Tresidder, Jack 2005. Stownik symboli. [The dictionary of symbols.] Warszawa: Wyd. RM.

Zimny, Rafał 2008. Kreowanie obrazów świata w tekstach reklamowych. [Creating of the images of the word in advertisement texts.] Warszawa: Wyd. Trio.

Zinken, Jörg 2004. Metaphors, stereotypes, and the linguistic picture of the world: Impulses from the Ethnolinguistic School of Lublin. Metaphorik, No. 7, pp. 115-136. http:// www.metaphorik.de/07/zinken.pdf, last accessed on 29 September 2012. 